\title{
Quail Performance at the Starter-Grower Period Fed by Commercial Diet with the addition of Ginger and Turmeric
}

\author{
Ikhwan Fauzan, Deden Sudrajat, and Elis Dihansih
}

Animal Husbandry Study Program, Faculty of Agriculture, Universitas Djuanda, Indonesia

\begin{abstract}
Ginger and turmeric can be used as feed additive in the quail's rations. An active substance in this Zingiberaceae family has good benefits for animals, especially quails. A research on the Quail Performance at the Starter-Grower Period fed commercial feed with the addition of ginger and turmeric had been conducted over the past five weeks. The purpose of this research was to know the effect of feed additive (ginger and turmeric flour) on the quail's performance since the starter period up to the grower period. The data were 240 two day old quails. The experimental design used was a Complete Random Design (CRD) with 4 treatments and 4 replications, i.e. P0: feed controls without any addition, P1: addition of $1 \%$ ginger flour; P2: the addition of $1 \%$ turmeric flour; $\mathrm{P} 3$ : the addition of $0.5 \%$ ginger flour plus $0.5 \%$ turmeric flour. The observed variables were the consumption of rations, body weights, FCR, mortality and depletion. The results showed that each of the treatment was not significantly different or had no effect on the performance of quails at the starter-grower period. It is necessary to do similar research by increasing the percentages administered to each of the treatments, so that the effect of administering the feed additive; i.e. ginger flour and turmeric flour can be obtained.
\end{abstract}

Keywords: ginger, quail performance, SQF turmeric, Zingiberaceae

Received 26 February 2018 | Revised 26 March 2018 | Accepted 27 March 2018

\section{Introduction}

The quail is a type of poultry other than chicken that has the potential to be a high egg producer. In Indonesia the quail is potentially important to be developed, because of its high meat and egg production. The japanese quail (Coturnix coturnix japonica) is widely reared for egg and meat production and also for experimental purposes. The type of broiler quail is usually male quail or unproductive quail. One of the factors that influences quail production performance is feed factor. Feed has an important role in quail rearing; therefore, careful attention must be addressed because the nutrients obtained by livestock comes from the feed. Some results of research are adapted by breeders to improve productivity results, and one of which is by giving antibiotics to stimulate growth. Some antibiotics can be obtained from herbs (phytobiotics), and herbs that

\footnotetext{
*Corresponding author at: Animal Husbandry Study Program, Faculty of Agriculture, Universitas Djuanda, Jl. Tol Ciawi No. 1, Bogor, Indonesia

E-mail address: tbikhwanfauzan@gmail.com
} 
can act as a phytobiotics is a group of Zingiberaceae plants such as ginger (Zingiber officinale) and turmeric (Curcuma domestica).

Administering ginger extract to broiler chicken mixed with drinking water will optimize the digestive organs to work maximally, increase appetite, make livestock healthier, optimize growth and productivity, reduce unpleasant odor in cages, maintain livestock metabolism system and maximize feed efficiency [1]. The objective of this study was determine the effect of dietary supplementation of ginger powder and turmeric powder on the production performance of Japanese quails.

\section{Materials and Method}

The study was conducted 33 days, from January 26 to February 28, 2017. The location of the study was CV SQF (Slamet Quail Farm), a quail breeding and production company, at Jalan Raya Pelabuhan II KM 19 Cikembar Sukabumi-West Java.

\subsection{Animals and Management}

Two hundred and forty 2-day old local quality quails of Japanese strain (Coturnix coturnix japonica), with an average weight of 9.00 grams. They were fed a commercial ration in the form of mash of BR-1 type during the starter period and SP-2 during the grower period. The feed were produced by PT Sinta Prima Feedmill., water, and commercial ginger flour and turmeric flour with trade name of rumah rudang produced by PT Rudang Cipta Persada. The variables observed in this study were (1) consumption of ration which was the amount of ration consumed by the quails during the treatment period, and the consumed ration was weighed every week; (2) the weight gain obtained by reducing the body weight after one week treatment with the initial weight of the quails; (3) ration conversion which was the result of consumed ration divided by one week's weight gain; and (4) the mortality rate obtained by dividing the number of dead quails with the initial number of quails at the time of treatment.

\subsection{Dietary Treatments}

The dietary treatments were as follows: (i) P0: Control feed without addition of ginger powder and turmeric powder; (ii) P1: Commercial feed $+1 \%$ ginger powder (iii) P2: Commercial feed $+1 \%$ turmeric powder, and (iv) P3: Commercial feed $+0.5 \%$ ginger powder and $0.5 \%$ turmeric powder.

\subsection{Experimental Design}

The design of the experiment was a Completely Randomized Design with four treatments and four replications. The data obtained were analyzed using ANOVA, followed by Duncan's double-distance test using the SPSS 16 program when the observed variables had significant differences. 


\subsection{Implementation Procedure}

During the cage drying period, the tools were prepared in order that the treatment on the quails could be done optimally. The preparation of the tools includes washing the quails' drinking and feeding containers, cutting the plywood board as the cage base, cutting the wire as the cover of the feeding container, closing the wall of the cage and checking the electrical installation in the cage and aviary. After the cage was dry and ready for use, the quails were then placed on each of the units according to the treatment scheme and the research design.

This research used a commercial ration in the mash form mixed with the ration of ginger flour and turmeric flour. Administering the ration was based on the requirement of every period: at the starter period 6-15 gram/head/day was administered gradually, and at the grower period 20 gram/head/day was administered. The procedure of ration administration was done by calculating every ration requirement per unit which was mixed with additional ration of each treatment.

Mixing the ration was done by inserting the commercial ration and feed additives into the plastic, then the mixture was stirred until the ration was evenly distributed. The ration was administered directly to each unit of the treatments in adlibitum once a day (i.e. in the morning).

Quail weighing using digital scale was conducted once a week by taking the sample of quails. The quail samples per unit was $20 \%$ or 3 heads, so the total number of sample was 15 heads. The data obtained were directly input into a data table and were directly averaged to obtain the value of the weight gain of each unit.

\section{Results and Discussion}

\subsection{Starter Period}

The results showed that the administration of ginger flour and turmeric flour in commercial feed had no significant effect $(\mathrm{P}>0.05)$ on all measured variables. The average rate of consumption in the starter period was $8.69 \mathrm{~g} / \mathrm{head} / \mathrm{day}$. Such amount was influenced by the level of energy and feed palatability on the quails. This finding is below the results of the research conducted by Elfawati [2] who found that the consumption of daily average of quail's ration ranged from 10.35 to $11.66 \mathrm{~g} / \mathrm{head} /$ day.

The insignificant difference of ration consumption was because the percentage of ingredients in each treatment did not affect the content of the ration. The research rations had similar qualities to the usual commercial rations that used to be administered so that the results did not affect the consumption rate. Sex, age, and body weight of the quails affected the ration consumption. The addition and replacement of damaged body cells was one of several benefits obtained from the ration consumption. The ration containing higher energy would lead to less ration consumption compared to the ration with low energy [3]. 
Table 1. Results of the Quail's Performance at the Starter Period

\begin{tabular}{lcccc}
\hline & P0 & P1 & P2 & P3 \\
\hline Consumption (g/head/day) & $8.58 \pm 0.30$ & $9.09 \pm 0.65$ & $8.56 \pm 0.36$ & $8.53 \pm 0.10$ \\
$\begin{array}{l}\text { Body Weight Gain } \\
\text { (g/head/day) }\end{array}$ & $3.96 \pm 0.24$ & $3.94 \pm 0.33$ & $3.78 \pm 0.26$ & $4.14 \pm 0.26$ \\
Feed Conversion Ratio & $2.23 \pm 0.10$ & $2.33 \pm 0.09$ & $2.32 \pm 0.20$ & $2.05 \pm 1,35$ \\
Mortality (Head) & $3(5 \%)$ & $7(11.67 \%)$ & $7(11.67 \%)$ & $5(8.33 \%)$ \\
Depletion (Head) & 3 & 7 & 7 & 5 \\
\hline
\end{tabular}

Notes: $\mathrm{P} 0=$ Commercial Feed without Addition (Control), P1 $=$ Commercial Feed $+1 \%$ Ginger Flour, P2 $=$ Commercial Feed $+1 \%$ Turmeric Flour, P3 $=$ Commercial Feed + $0.5 \%$ Ginger Flour $+0.5 \%$ Turmeric Flour

Body weight gain is one of several criteria used to measure the quail's growth. The increase in body weight is a reflection of the growth rate of quails [4]. The body weight gain within the 3 week starter period can be seen in Table 2. The quail's body weight gain is defined as the increase of the quail's weight every week and such increase will develop since hatching (DOQ) until it gains its maturity in which a quail will decrease its growth rate [5].

Table 2. Final Quails' Body Weight at the Starter Period

\begin{tabular}{cccc}
\hline \multirow{2}{*}{ Treatment } & \multicolumn{2}{c}{ Starter Period } & $\begin{array}{c}\text { Total of Body Weight } \\
\text { Growth } \\
\text { (g) }\end{array}$ \\
\hline P0 & $\begin{array}{c}\text { Initial Weight } \\
(\mathbf{g})\end{array}$ & $\begin{array}{c}\text { Final Weight } \\
(\mathbf{g})\end{array}$ & 119.52 \\
P1 & 9.15 & 128.67 & 123.53 \\
P2 & 9.05 & 132.58 & 116.36 \\
P3 & 8.72 & 125.08 & 128.61 \\
\hline
\end{tabular}

In this research, the quail's body weight gain always increased every week. The variance test indicated that the treatment did not affect the quails' body weight gain or the quails' body weight gain was not significantly different $(\mathrm{P}>0.05)$. In the starter period, the average rate of body weight gain was 3.95 grams/head/day. The result of this statistical analysis has a value above the results of the research conducted by Djailani [6] who found that the average increase in the quail's body weight was 2.12 grams/head/day.

The quail's body weight gain will increase at the age of 14 days, then will continue to increase until the age of 35 days [7]. The quail growth is influenced by several factors including genetic factors, rations, environment and other factors. The ration ratio is very influential on the growth of quail's body weight, especially the existing nutrients contained in the rations such as energy and protein [8].

The value of the ration conversion was obtained based on the comparison of the amount of feed consumed with the products (eggs or body weight gain). Livestock rearing, especially poultry, should consider the efficiency of the ration which is obtained from the conversion of the ration. If the conversion value of the ration is low or small, the ration application is efficient [9]. 
Table 3. Quail's Feed Conversion Ratio at the Starter Period

\begin{tabular}{cccccc}
\hline Conversion & P0 & P1 & P2 & P3 & Average \\
\hline $1^{\text {st }}$ Week & $1.61 \pm 0.24$ & $1.84 \pm 0.61$ & $1.66 \pm 0.47$ & $1.58 \pm 0.44$ & $1.67 \pm 0.42$ \\
$2^{\text {nd }}$ Week & $2.65 \pm 0.61$ & $2.47 \pm 0.58$ & $2.77 \pm 0.73$ & $2.28 \pm 0.25$ & $2.54 \pm 0.54$ \\
$3^{\text {rd }}$ Week & $2.41 \pm 0.54$ & $2.67 \pm 0.45$ & $2.52 \pm 0.21$ & $2.29 \pm 0.26$ & $2.47 \pm 0.38$ \\
\hline Average & $2.23 \pm 0.10$ & $2.33 \pm 0.09$ & $2.32 \pm 0.20$ & $2.05 \pm 1.35$ & $2.23 \pm 0.17$ \\
\hline
\end{tabular}

During the starter period, it was found that the average rate of the ration conversion on each treatment ranged from 2.05 to 2.33 , and the overall ration conversion rate during the research at the starter period was 2.23 .

The analysis of variance showed that the overall treatment did not have a significant effect on the conversion of the ration $(\mathrm{P}>0.05)$. This indicated that the administration of $1 \%$ ginger flour, $1 \%$ turmeric flour, and $0.5 \%$ ginger flour plus $0.5 \%$ turmeric flour did not affect the conversion rate of the ration.

The ration conversion rate during the research at the starter period ranged from 1.58 to 2.67. Such result of statistical analysis was considered good when compared to the results of the observation done by Hazim et al. [10] that quails had a ration conversion rate ranging from 3.76 to 4.71. In addition, the result of this statistical analysis was also very good when compared to the results of the observation done by Sumbawati [11] stating that the quail's ration conversion rate ranged from 3.00 to 3.61. Nevertheless, it is lower than the results of the observation done by Mufti [12] arguing that the average conversion of ration in quail was 4.30 with a range of 4.03-4.73.

From the above discussion, it can be said that the quail's ration conversion at the starter period was very good. The result was in line with the statement of Pujiwati et al. [13] arguing that the smaller the value of the feed conversion was, the more efficient the feed use would be, and vice versa. The ration conversion was used as a parameter to measure feed efficiency during the rearing period.

Differences in the rate of ration conversion are due to differences in the ration consumption and body weight growth [14]. According to Amrulloh [15], the factors affecting the rate of ration conversion are the ration quality, ration forms, ration administration technique, ration consumption and body weight growth.

The number of mortality of the quails during the research was 22 quails of the total 240 quails. The factors causing the quails' death were: (i) the quails plunged into the drinking container, and (ii) the weak quails tended to fall down and were then stepped on by other quails. Based on the table above, the highest mortality rate took place in the first week of the P2 treatment (1\% turmeric flour). The percentage of the quails that died during the starter period was $9.16 \%$ 
which was considered a very good result because, according to Wuryadi [16], the minimum mortality rate of the total population was $40 \%$.

Table 4. Quail Mortality at the Starter Period (head)

\begin{tabular}{|c|c|c|c|c|c|}
\hline \multirow{2}{*}{$\begin{array}{l}\text { Mortality } \\
\text { (head) }\end{array}$} & \multicolumn{4}{|c|}{ Treatment } & \multirow{2}{*}{ Total } \\
\hline & P0 & P1 & $\mathbf{P 2}$ & P3 & \\
\hline $1^{\text {st }}$ Week & 2 & 3 & 4 & 2 & 11 \\
\hline $2^{\text {nd }}$ Week & 1 & 2 & 2 & 3 & 8 \\
\hline $3^{\text {rd }}$ Week & 0 & 2 & 1 & 0 & 3 \\
\hline Total & $3(5 \%)$ & $7(11.67 \%)$ & $7(11.67 \%)$ & $5(8.33 \%)$ & $\begin{array}{c}22 \\
(9.16 \%)\end{array}$ \\
\hline
\end{tabular}

In the first week, the rate of depletion obtained was very high (11 quails) and was the peak of depletion at the starter period, after which the rate decreased because the quails' immune system was getting better and the death during the rearing could be minimized optimally.

Table 5. Quail Depletion at the Starter Period

\begin{tabular}{|c|c|c|c|c|c|}
\hline \multirow{2}{*}{$\begin{array}{c}\text { Depletion } \\
\text { (head) }\end{array}$} & \multicolumn{4}{|c|}{ Treatment } & \multirow{2}{*}{ Total } \\
\hline & P0 & P1 & $\mathbf{P 2}$ & P3 & \\
\hline $1^{\text {st }}$ Week & 2 & 3 & 4 & 2 & 11 \\
\hline $2^{\text {nd }}$ Week & 1 & 2 & 2 & 3 & 8 \\
\hline $3^{\text {rd }}$ Week & 0 & 2 & 1 & 0 & 3 \\
\hline Total & 3 & 7 & 7 & 5 & 22 \\
\hline
\end{tabular}

\subsection{Grower Period}

There was a difference in the rearing system at the grower period, sexing was done on the quails of the previous period. The male quails were eliminated or separated from the population, and only the female quails were reared for further observation on their performance. The following table presents the result of the observation on the quails at the grower period (21-35 days of age).

The result of variance analysis explained each treatment, i.e. the addition of ginger flour and turmeric flour in the ration at the grower period did not affect the feed consumption. The average rate of consumption at the grower period was $17.48 \mathrm{grams} / \mathrm{head} / \mathrm{day}$. The result of this statistical analysis was slightly different from the results of the research done by Sudrajat et al. [17] arguing that the quail's ration consumption was $18.8 \mathrm{~g} / \mathrm{head} /$ day.

Meanwhile, when compared to the results of observation done by Sumbawati [11] that the quail's ration consumption was $109.69-135.59 \mathrm{~g} / \mathrm{head} /$ week or equals to $17.52 \mathrm{~g} / \mathrm{head} / \mathrm{day}$, the result of this research was almost appropriate. However, according to Kusumoastuti (1992), the result of statistical analysis of this research was very low because the average feed consumption ranged from 127.12 to $165.15 \mathrm{~g} /$ head/week or $20.87 \mathrm{~g} / \mathrm{head} /$ day. 
One of the aspects related to body weight gain was a change. In addition, body weight gain also served as the parameter for measuring a growth process. Substantial process in the production process observed from the body weight gain was a positive side of the growth of livestock.

Table 6. Results of Quail Performance at the Grower Period

\begin{tabular}{ccccc}
\hline & P0 & P1 & P2 & P3 \\
\hline $\begin{array}{c}\text { Consumption } \\
\text { (g/head/day) }\end{array}$ & $17.11 \pm 0.62$ & $18.29 \pm 2.25$ & $17.40 \pm 1.39$ & $17.14 \pm 0.87$ \\
$\begin{array}{c}\text { Body Weigh Gain } \\
\text { (g/head/day) }\end{array}$ & $3.11 \pm 0.75$ & $3.41 \pm 0.31$ & $3.13 \pm 0.72$ & $3.46 \pm 0.19$ \\
Ration Conversion & $5.88 \pm 1.22$ & $5.88 \pm 1.07$ & $5.98 \pm 1.69$ & $5.01 \pm 0.37$ \\
Mortality (Head) & 0 & 0 & 0 & 0 \\
Depletion (Head) & 30 & 26 & 22 & 21 \\
\hline
\end{tabular}

The result of the analysis of variance was the result of sexing on the quails of the previous period, the data were 22-35 day old female quails. The variance analysis result showed that there was no effect on the quails' body weight gain at the grower period or the effect was not significantly different $(>0.05)$ in each replication.

The average rate of the total body weight gain was $3.28 \mathrm{grams} / \mathrm{head} /$ day. This result was different from the result of the starter period. The average rate of the weight gain at the grower period was higher when compared to the result of the observation done by Widodo [19] who found that the average rate of body weight gain was $2.93 \mathrm{grams} / \mathrm{head} / \mathrm{day}$. According to Mahfudz [20], the increased protein digestion affected the increase of the daily body weight gain because it would facilitate protein metabolism during the growth period. If the ration quality is good, the body weight gain will increase.

Table 7. Body Weight Gain of Female Quails at the Grower Period (gram/head/day)

\begin{tabular}{cccccc}
\hline Conversion & P0 & P1 & P2 & P3 & Average \\
\hline $4^{\text {th }}$ week & $2.68 \pm 0.75$ & $3.46 \pm 0.97$ & $3.55 \pm 0.89$ & $3.52 \pm 0.28$ & $3.30 \pm 0.78$ \\
$5^{\text {th }}$ week & $3.55 \pm 0.99$ & $3.35 \pm 1.16$ & $2.71 \pm 0.58$ & $3.40 \pm 0.54$ & $3.25 \pm 0.84$ \\
\hline Average & $3.11 \pm 0.75$ & $3.41 \pm 0.31$ & $3.13 \pm 0.72$ & $3.46 \pm 0.19$ & $3.28 \pm 0.52$ \\
\hline
\end{tabular}

The variance analysis results showed that each replication did not affect the quail's ration conversion rate at the grower period. The average value of the ration conversion per treatment ranged from 5.01 to 5.98 , with an overall mean value of 5.68. This result was good when compared to the result of the observation done by Subekti et al. [21] who found the average ration conversion rate ranged from 5.87 to 5.36 and Sudrajat [17] who found that the ration conversion rate was 6.64 . 
Table 8. Feed Conversion Ratio of Female Quails at the Grower Period

\begin{tabular}{cccccc}
\hline Conversion & P0 & P1 & P2 & P3 & Average \\
\hline $4^{\text {th }}$ week & $6.45 \pm 1.71$ & $5.50 \pm 1.78$ & $4.89 \pm 1.28$ & $4.73 \pm 0.58$ & $5.39 \pm 1.45$ \\
$5^{\text {th }}$ week & $5.32 \pm 1.30$ & $6.24 \pm 2.55$ & $7.05 \pm 2.16$ & $5.28 \pm 0.75$ & $5.97 \pm 1.80$ \\
\hline Average & $5.88 \pm 1.22$ & $5.88 \pm 1.07$ & $5.98 \pm 1.69$ & $5.01 \pm 0.37$ & $5.68 \pm 1.13$ \\
\hline
\end{tabular}

Quail's mortality was not found during the grower period indicating that the metabolic system had improved well. The previous deaths were caused by the weakness of quails so that the deaths due to plunging into the drinking container and being stepped on by other quails were no longer existed. According to Woodard et al. [22], most of quails died at their young age, and the mortality percentage of female quails tended to be higher than male quails. Several factors affecting the quail mortality rate were rearing management, ration intake, ration administration, sanitation, temperature, humidity and the quality of the baby quail chicks [3].

Table 9. Mortality of Female Quails at the Grower Period (head)

\begin{tabular}{|c|c|c|c|c|c|}
\hline \multirow{2}{*}{$\begin{array}{c}\text { Mortality } \\
\text { (head) }\end{array}$} & \multicolumn{4}{|c|}{ Treatment } & \multirow{2}{*}{ Tota } \\
\hline & P0 & P1 & $\mathbf{P 2}$ & P3 & \\
\hline $4^{\text {th }}$ week & 0 & 0 & 0 & 0 & 0 \\
\hline $5^{\text {th }}$ week & 0 & 0 & 0 & 0 & 0 \\
\hline Total & 0 & 0 & 0 & 0 & 0 \\
\hline
\end{tabular}

On the transition from the starter period to the grower period, sexing process to male quails was carried out. Male quails were eliminated or removed from the cages. This was done because the eggs that would be produced were intended for consumption or commercial eggs.

Of the total remaining quails at the starter period (218 heads), the result of the sexing found 99 male quails. These male quails were distributed in different experimental groups: 30 heads in $\mathrm{P} 0,26$ heads in $\mathrm{P} 1,22$ heads in $\mathrm{P} 2$ and 21 heads in $\mathrm{P} 3$.

Table 10. Depletion of Female Quails at the Grower Period

\begin{tabular}{|c|c|c|c|c|c|}
\hline \multirow{2}{*}{ Depletion (head) } & \multicolumn{4}{|c|}{ Treatment } & \multirow{2}{*}{ Total } \\
\hline & P0 & $\mathbf{P 1}$ & $\mathbf{P 2}$ & P3 & \\
\hline $4^{\text {th }}$ week & 30 & 26 & 22 & 21 & 99 \\
\hline $5^{\text {th }}$ week & 0 & 0 & 0 & 0 & 0 \\
\hline Total & 30 & 26 & 22 & 21 & 99 \\
\hline
\end{tabular}

\section{Conclusion}

The addition of feed additive, i.e. ginger flour, turmeric flour and combination of ginger flour and turmeric flour, did not affect the quail (Coturnix coturnix japonica) growth performance at the starter-grower period. 


\section{REFERENCES}

[1] Sudarsono, "Tanaman kunyit manfaat khasiat dan kandungan bagi kesehatan," 1996. [Online] Available : http:warnadunia.com.

[2] Elfawati, "Pengaruh pemakaian tepung umbi talas (Xanthosoma saginitifolium) dan penambahan metionin dalam Ransum puyuh periode pertumbuhan," Jurnal Peternakan, vol. 3, no. 1, pp. 10-17, 2006.

[3] M. Rasyaf, Manajemen Peternakan Ayam Broiler. Jakarta: Penebar Swadaya, 2000.

[4] A. D. Tillman, et al, Ilmu Makanan Ternak Dasar. Yogyakarta: Gadjah Mada University Press, 1998.

[5] E. S. E. Hafez, and I. A. Dyer. Animal Growth and Nutrition. Philadelphia: Lea and Febiger, 1969, pp. 6-7.

[6] L. Djaelani, M. Mukhtar, and S. D. Sri, "Level pemberian dedak jagung fermentasi dalam ransum terhadap pertambahan bobot badan dan efisiensi ransum burung puyuh (Coturnix coturnix japonica) fase pertumbuhan," Jurnal Belibis Sains (JBS), vol. 1, no. 1, pp. 16-17, 2015.

[7] W. Rahayuningtyas, M. Susilowati, and A. Ghani, "Pengaruh Umur terhadap Pertambahan Bobot Badan dan Kadar Hormon Pertumbuhan pada Burung Puyuh (Coturnix-coturnix japonica L.) Jantan,” Skripsi, Jurusan Biologi Universitas Negeri Malang, Malang, 2014.

[8] E. Sujana, T. Wiwin, and W. Tuyi, "Evaluation on quails (Coturnix coturnix japonica) growth performance among the breeding centre of village communities in West Java," Lucrari Stiintifice - Seria Zootehnie, vol. 58, no. 1, pp. 44-49, 2012.

[9] M. A. Ensminger, Poultry Science (Animal Agriculture Series). $3^{\text {rd }}$ Edn. Illinois: Interstate Publishers, Inc, Danville, 1992.

[10] J. Hazim, et al., "Effect of dietary suplementation with different oil on productive and reproductive performance of quail," International Journal Poultry Science, vol. 9, no. 5, pp. 429-435, 2010.

[11] Sumbawati, "Penggunaan Beberapa Tingkat Zeolit dengan Tingkat Protein dalam Ransum Burung Puyuh terhadap Produksi Telur, Indeks Putih Telur dan Indeks Kuning Telur," Thesis, Fakultas Peternakan Institut Pertanian Bogor, Bogor, 1992.

[12] M. Mufti, "Dampak fotoregulasi dan tingkat protein ransum selama periode pertumbuhan terhadap kinerja burung puyuh penelur," Thesis, Pascasarjana Institut Pertanian Bogor, Bogor, 1997.

[13] R. Pujiwati, W. Busono, and O. Sofjan. Efek penggunaan beberapa sumber kalsium dalam pakan terhadap penampilan produksi ayam petelur. Malang, 2013.

[14] Achmanu, Muharlien, and Salaby, "Pengaruh lantai kandang (rapat dan renggang) dan imbangan jantan betina terhadap konsumsi pakan, bobot telur, konversi pakan dan tebal kerabang pada burung puyuh," Jurnal Ternak Tropika, vol. 12, no. 2, pp. 1-14, 2011.

[15] I. K. Amrullah. Nutrisi Ayam Petelur. Bogor: Lembaga Satu, Gunungbudi, 2003.

[16] S. Wuryadi. Buku Pintar Beternak dan Bisnis Puyuh. Jakarta: Agromedia Pustaka, 2011.

[17] D. Sudrajat, D. Kardaya, E. Dihansih, and S. F. S. Puteri SFS, "Performa produksi telur burung puyuh yang diberi ransum mengandung kromium organik," JITV, vol. 19, no. 4, pp. 257-262, 2014.

[18] E. S. Kusumoastuti, "Penggunaan Pengaruh Zeolit dalam Ransum Puyuh (Coturnix coturnix japonica) terhadap Produksi dan Kualitas Telur pada Periode Produksi Umur 1319 Minggu," Thesis, Fakultas Peternakan Institut Pertanian Bogor, Bogor, 1992.

[19] A. R. Widodo, H. Setiawan, Sudiyono, Sudibya, and R. Indreswari, "Kecernaan nutrien dan performan puyuh (Coturnix coturnix japonica) jantan yang diberi ampas tahu fermentasi dalam ransum," Tropical Animal Husbandry, vol. 2, no. 1, pp. 51-57, 2013. 
[20] L. D. Mahfudz, "Efektifitas oncom ampas tahu sebagai bahan pakan ayam pedaging," Animal Production, vol. 8, no. 1, pp. 108-114, 2006.

[21] S. Subekti, et al, "Penggunaan tepung daun katuk dan ekstrak daun katuk (Sauropus androgynus L. Merr) sebagai substitusi ransum yang dapat menghasilkan produk puyuh jepang," JITV, vol. 11, no. 4, pp. 254-259, 2006.

[22] A. E. Woodard et al. Japanese quail husbandry in the laboratory. California: University of California, 1973. 